\title{
Exploring the relationship of law and emotions in the context of Disability Rights jurisprudence
}

\author{
Sanjay Jain ${ }^{1}$
}

Accepted: 26 October 2021 / Published online: 27 November 2021

(c) The Author(s), under exclusive licence to O.P. Jindal Global University (JGU) 2021

\begin{abstract}
In this article, I attempt to explore the relationship between law and emotions in the context of disability rights jurisprudence. It is argued that the scholarship on law and emotions has not yet grappled with either the ableist legal theory or infusion of negative emotions in law vis-à-vis physical and mental disability. Using the conceptual framework proffered by Terry Maroney, this article situates the disability rights jurisprudence in the scholarship on law and emotions with critical examination of the United Nations Convention on Rights of Persons with Disabilities (UNCRPD), the Constitution of India, and the Rights of Persons with Disability Act 2016 (RPwD Act). A case has been made out to foster infusion of positive emotions of dignity, empathy, and compassion in legal regime to combat stigmatisation of physical and mental disability, garner respect for difference and diversity and recognise disability as part of humanity.
\end{abstract}

Keywords Law $\cdot$ Emotions $\cdot$ Equality $\cdot$ Dignity $\cdot$ Physical and mental disability

\section{Introduction}

The modest aim of this paper is to grapple with the relationship of law and emotion and comprehend its dynamics. In this paper, I do not intend to engage in a critical debate about the definitions of emotion and law and simply draw from the consensus of the scholars.

\subsection{Defining emotion}

According to Martha Nussbaum, the Anglo-American tradition "connects emotions closely with thought about important benefits and harms, and thus, as well, with

Sanjay Jain

ss.jain54@gmail.com

1 ILS Law College, Pune, India 
prevailing social norms concerning what benefits and harms are rightly thought important. ${ }^{1}$ Nussbaum draws on Aristotelian virtue ethics to contest the mind-body distinction in the conceptualisation of emotions and perceives the faculty of reasoning both as a neuroscientific and social phenomenon. ${ }^{2}$ Nussbaum endorses this approach as it fosters moral education and helps to generate social emotions. ${ }^{3}$ The same can be used as an evaluative standard to assess the reasonableness and distinguish between positive and negative emotions. In this light, for this article, the term 'emotion' is broadly defined to connote a variety of meanings attached to it by scholars to include emotion, feelings, affect, and mood. It is also possible to distinguish between public and private emotions. The latter relates to the feelings or moods of individuals in the private sphere, whereas the former infuses and informs the social, political, and legal institutions. Thus, empathy, dignity and compassion can broadly be identified as positive public emotions, whereas hate, anger, and disgust are negative emotions adversely affecting public law in the realm of law and disability. I do not propose to engage in the debate about the correctness of these varied meanings.

The related question-whether the appraisal of emotions with reference to social norms and vice-a-versa is antithetical to the conception of society committed to respect for pluralism-can be addressed in negative by endorsing the view of Nussbaum. Nussbaum assumes that both law and emotions are the sources of social norms; the law may be viewed as a public justification in light of the Rawlsian notion of political liberalism based on overlapping consensus to appraise emotions and vice-a-versa. ${ }^{4}$

So far as human experiences are conceptualised as emotions, there is a fair amount of agreement in the philosophical and popular traditions. ${ }^{5}$ A host of human experiences are called emotions or passions including joy, grief, fear, anger, hatred, pity, compassion, envy, jealousy, hope, guilt, gratitude, shame, disgust, and love. ${ }^{6}$

According to Maroney, the meaning of emotion is also relative to a particular perspective and its operative definition. ${ }^{7}$

For example, Damasio distinguishes "emotions," by which he means a series of nonconscious processes mapped in the body and brain in response to emotionally competent stimuli, and "feelings," the conscious experiences of happi-

\footnotetext{
1 Martha C Nussbaum, Hiding from Humanity: Disgust, Shame, and The Law (Princeton University Press 2004) 22.

2 Martha C Nussbaum, Upheavals of Thought the Intelligence of Emotions (Cambridge University Press 2003) ch 1, 19-88. It is submitted that reliance on Aristotelian thought in the context of 'disability' is problematic without its reconceptualisation in light of Stoicism; Garret Merriam, 'Rehabilitating Aristotle: A Virtue Ethics Approach to Disability and Human Flourishing' in D Christopher Ralston et al., (eds), Philosophical Reflections on Disability (Springer 2010) 133-151.

3 Nussbaum, Hiding from Humanity (n 1).

4 Ibid. 22-23.

5 Ibid. 23.

6 Ibid.

7 Terry A Maroney, 'Law and Emotion: A Proposed Taxonomy of an Emerging Field' in Susan A Bandes et al, (eds), Research Handbook on Law and Emotion (Edward Elgar Publishing Limited 2021) 534.
} 
ness, sadness, and so on that are triggered by emotions; but what he calls feelings are what most non-scientists, and some scientists, would call emotions. ${ }^{8}$

Moreover, other socio-psychological conceptions like 'attachment,' apart from implicating the study of emotion, also play a vital role in its operationalisation. ${ }^{9}$ In this light, it is arguable that social norms ${ }^{10}$ of human flourishing and well-being embody the public emotions of dignity, fraternity, equanimity, and empathy.

Emotions can be both incidental and integral; the former is independent of the judgment to be made, while the latter is a reaction to the evidence or a required judgment. ${ }^{11}$ On both these counts, they are not the intended consequences. ${ }^{12}$ There is substantial literature both defining emotion and distinguishing it from phenomena like mood, affect, and feeling. However, these phenomena are not hermetically sealed and overlap into one another, and also have their substantive sub-categories, "for example, "affect" generally refers to the perceived "goodness" or "badness" of a given stimulus, but often is used as an umbrella term encompassing both "emotions" and "mood," the mood is often defined as a "diffuse, non-object-specific feeling-state." 13

In other words, defining emotion is far from easy. But to reiterate, public emotions like those mentioned earlier have the following epistemic properties:
a. promotion of well-being;
b. human flourishing;
c. fostering respect for difference; and
d. dispensing with barriers inhibiting socio-political and legal intercourse between social groups.

\subsection{Defining law}

Having defined emotions pragmatically, I will also conceptualise law. Controversy around the definition of law is too well-known to be rehearsed, but suffice it to say that, for this paper, law refers to a set of norms regulating both public and private conduct of individuals, their relationship inter se, and the State ${ }^{14}$.

\footnotetext{
${ }^{8}$ Ibid. 540. (Internal citations omitted).

9 Ibid.

10 The researcher advocates a broad conception of norms constitutive of both rules and principles.

11 Neal Feigenson and Jaihyun Park, 'Emotions and Attributions of Legal Responsibility and Blame: A Research Review’ (2006) 30(2) Law and Human Behaviour 143.

12 Ibid.

13 Maroney, 'Law and Emotion' (n 7) 540.

14 Sanjay Jain, 'Towards Unrestricted and Disability Inclusive Legal Theory: Random Reflections' (2020) 14 ILS Law Review 22-41.
} 


\subsection{Defining disability}

It is also imperative to briefly elaborate on the conception of disability deployed for this paper. I advocate the symbiosis of social and human rights models of disability ${ }^{15}$ to focus equally on the external barriers and lived experiences of persons with disabilities (PWDs) borne out of impairments. In my opinion, disability has to be viewed on a continuum; the dichotomy between disabled and non-disabled is untenable, but to make discussion practical, the same is maintained.

For a systematic discussion, I map the relationship of law and emotion by identifying two broad approaches evolved by Maroney and refer to a six-pronged formulation for analysing the nuances of the relationship of law and emotion. While analysing these approaches, I bring into sharp relief the relationship of law and emotions in the context of disability for evolving an inclusive society. I also expose the embodiment of negative emotions into legal norms and make a case for evolving a protective core of law infused with positive public emotions. Reference is made to prominent scholars like Martha Nussbaum, Robin West, and Goffman, to argue that despite the law being predominantly ableist, it is viable to go for reforms rather than questioning its authority. Even liberal legalism, in my opinion, can be infused with public emotions of empathy, compassion and dignity, and emotions like disgust and shame can be brought into play in progressive connotation.

\section{Mapping the relationship of emotions and law}

Emotion has made its appearance in the domain of law directly and indirectly. ${ }^{16}$ However, of course, there is a counterpoint advocated by legal positivists holding that law is a reason free from emotions. ${ }^{17}$ The present conception of liberal legalism, a dominant narrative, frowns upon the relationship of law and sentiments, resulting in the creation and recreation of legal agents as unsentimental subjects "un-empathic regarding the inner lives of others and unsympathetic to their suffering. ${ }^{18}$ Borrowing from Peter Gabel, Robin West captures the idea that 'the law that grounds contemporary liberal legalism actively alienates us from our moral sentiments: its formalism blunts or kills communitarian feeling, its lean toward objectivity erases subjective and intersubjective life, its individualistic assumptions deny our

\footnotetext{
15 Anna Lawson and Angharad E Beckett, 'The Social and Human Rights Models of Disability: Towards a Complementarity Thesis' (2020) 25(2) The International Journal of Human Rights 348; T Degener, 'Disability in a Human Rights Context' (2016) 5(3) Laws 35.

16 See Brian H Bornstein and Richard L Wiener, 'Emotion and the Law: A Field Whose Time Has Come' in Brian H Bornstein et al., (eds), Emotion and the Law: Psychological Perspectives (2012) 1-12.

17 Be it Austin or Kelsen, the concept of law is viewed as rule bound, either as a command of sovereign or a hierarchal system of rules, without directing attention to its content.

18 Robin West, 'Law's Sentiments' in Bandes et al, (eds), Research Handbook on Law and Emotion (n 7) 44-61.
} 
connections to each other and push each of us to deny them likewise. ${ }^{19}$ However, since the early 1980s, scholars have consistently challenged this view in the domain of law $^{20}$ and other social sciences. ${ }^{21}$ There are many illustrations of the conscious incorporation of emotions in the process of policies and laws. Thus, one of the significant indicia of criminal trials is a condemnation of perpetrators for the commission of criminal acts if the same is proportionate to the gravity of the offence. ${ }^{22}$ The emotional features of such condemnation are anger, disgust, and contempt that people have towards wrongdoers committing heinous crimes against society. ${ }^{23}$ Similarly, emotions also influence civil trials, e.g., awarding damages or compensation for emotional distress, nervous shock, defamation etc.

At times, it is difficult to determine whether a particular project is about both law and emotion. To address this difficulty, reference to two-pronged framework proffered by Maroney is in order. ${ }^{24}$ Firstly, the contemporary law-and-emotion scholarship is based on the belief that human emotion is amenable to scrutiny and study and is 'highly relevant to the theory and practice of law.' ${ }^{25}$ Secondly, 'such scholarship explicitly directs itself to both sides of the "and";' taking on the question regarding law and engaging with a perspective grounded in the study or theory of emotions. ${ }^{26}$ By drawing on this framework, many authors have made fervent attempts to recognise law and emotion as a distinct rubric of scholarship. ${ }^{27}$ Similarly, empirical studies have been made around emotion-laden questions such as the effects of induced anger on decision-making. ${ }^{28}$

\footnotetext{
${ }^{19}$ Ibid. See also Peter Gabel, 'The Phenomenology of Rights-Consciousness and the Pact of the Withdrawn Selves' (1984) 62 Texas Law Review 1563-1598; Peter Gabel, The Desire for Mutual Recognition: Social Movements And The Dissolution Of The False Self (Routledge 2018); Peter Gabel, Another Way of Seeing: Essays on Transforming Law, Politics and Culture (Quid Pro Books 2013).

${ }^{20}$ Brennan J observed, 'the greatest threat to due process principles is formal reason severed from the insights of passion.' Defining 'passion' he added, 'the range of emotional and intuitive responses to a given set of facts or arguments, responses which often speed into our consciousness far ahead of the lumbering syllogisms of reason' - does not 'taint the judicial process, but is in fact central to its vitality,' William J Brennan Jr., 'Reason, Passion, and the Progress of the Law' (1988) 10(3) Cardozo Law Review.

${ }^{21}$ M L Bailey and Kimberly, 'Writing Histories of Law and Emotions' (2017) 38(2) Journal of Legal History 117; Liesbeth Huppes-Cluysenaer and Nuno M M S Coelho (eds), Aristotle on Emotions in Law and Politics (Springer International Publishing 2018).

${ }^{22}$ See The Indian Penal Code 1860 ss 96-106; For western scholarship, see Marc W Pearce, 'Civilly Committing Criminals: An Analysis of the Expressive Function of Nebraska's "Dangerous Sex Offender" Commitment Procedure' (2007) 85 Nebraska Law Review 575.

${ }^{23}$ See Indian Penal Code s 300, 'Exceptions to the criminal liability for offence of culpable homicide amounting to murder.' The exception of sudden and grave provocation is the most prominent candidate diminishing criminal liability.

${ }^{24}$ Maroney, 'Law and Emotion' (n 7) 541.

25 Ibid. 540.

${ }^{26}$ Ibid.

${ }^{27}$ M N S Sellers, Law, Reason, and Emotion (Cambridge University Press 2017); Bandes et al., (eds), Research Handbook on Law and Emotion (n 7).

${ }^{28}$ See Heidi Li Feldman, 'Prudence, Benevolence, and Negligence: Virtue Ethics and Tort Law' (2000) 74(4) Chicago-Kent Law Review 1431; Cass R Sunstein, 'The Laws of Fear' (2002) 115(4) Harvard Law Review 1119.
} 
In the context of disability, it is quite possible to undertake empirical research on emotion-laden questions as well, viz to what extent adjudication is induced by sympathy and prejudice while engaging with the right to employment of PWDs. ${ }^{29}$ Equally, the scholarship of law and emotion has to be viewed beyond self-identified works. Thus, supporters of the social model of disability identifying handicaps in social barriers would be motivated by empathy, whereas, those advocating an interactive model attaching a weight to the lived experiences of PWDs arising out of impairments and pain would pay equal attention to the emotions of dignity and selfdetermination along with empathy. David Badcott observes,

... that conscience and emotional dignity are vital components of a sense of self, and importantly, awareness of self (self-regard) opens the door to awareness of others as others (other regard). And the relationships between self and others constitute the arena for all social intercourse including expressions of concern and respect. ${ }^{30}$

According to Badcott, emotional dignity being one of the moral concepts is 'often reinforced by ritual and sometimes enforced by law. ${ }^{31}$ In other words, disability rights scholars engage with the question of identification of core disability empowering emotions and interaction of the same with law and society. ${ }^{32}$

Moreover, the scholarship assumes significance to interrogate and problematise both emotions and law from the standpoint of ableism. ${ }^{33}$ The attention is directed towards the ableist structure of law as a default resulting in exclusion and pathology of PWDs. Similarly, it is also worth focusing on how disability-affective emotions of shame and disgust pan out in law and social behaviour. Suppose one of the characteristics of emotion is fostering moral education and being part of social norms. In that case, its conceptualisation must be beyond a particular ideology like ableism as the liberal society is diverse and motivates inculcation for the difference. So is the case with the conception of law to be suited to the structure of such society.

Apart from respecting inter-subjectivity, it must create conditions for fulfilling of the desire for mutual recognition and respect amongst its members. In short, the anti-ableist emotions, which I characterise as public emotions, must transform the conventional conception of law, ableism and disablism. It may sound odd to transform emotions by law, but on a utopian plane, it is possible. As a matter of fact, UNCRPD has become the first international legal instrument to have attributed the properties of law-ness and enforceability to the public emotions of dignity and empathy.

\footnotetext{
${ }^{29}$ Martha C Nussbaum, 'Protecting Citizens from Shame' in Nussbaum, Hiding from Humanity (n 1) ch 6.

${ }^{30}$ David Badcott, 'The Basis and Relevance of Emotional Dignity' (2003) 6 Medicine, Health Care and Philosophy 123, 125. (Internal citations omitted).

${ }^{31}$ Ibid.

${ }^{32}$ Fiona Kumari Campbell, Contours of Ableism: The Production of Disability and Abledness (Palgrave Macmillan 2009).

${ }^{33}$ Bob Pease, 'Ableist Relations and the Embodiment of Privilege' in Undoing Privilege: Unearned Advantage in a Divided World (ZED Books 2010).
} 


\subsection{Scholarship on law and emotion in India}

Unlike the West, in India, I have not come across any direct studies engaging with the relationship of law and emotion. However, the same can be illustrated in enactment as well as adjudication of law implicitly. Justice Bhagwati under the influence of the emotion of compassion for life, engaged in in-depth research for three years before delivering his famous dissenting opinion in Bachan Singh v. State of Punjab ${ }^{34}$ declaring the death penalty to be unconstitutional. After the emergency, under the influence of emotions of empathy and fraternity and to be seen as a sentinel on the qui vive, all the six judges forming the bench in Maneka Gandhi v. Union of India ${ }^{35}$ delivered separate judgments enduring the doctrines of inalienable and transcendental fundamental rights enshrined in Part III of the Constitution of India. Under the influence of the emotional phenomenon of counter-majoritarianism, Justice Hidayatullah ${ }^{36}$ perceived fundamental rights as unamendable despite a contrary textual matrix of Part III.

We are also aware of an attempt made by Indira Gandhi, the then Prime Minister of India, during the emergency of 1975 to generate emotions of patriotism in the hearts and minds of citizens by introducing fundamental duties ${ }^{37}$ in the Constitution. A careful look at these duties makes it evident how the notions of compassion, ${ }^{38}$ dignity, ${ }^{39}$ patriotism, ${ }^{40}$ love,${ }^{41}$ have been at play in public law.

The story is not any different in the Parliament. The Prohibition of Child Marriage Act 2006 was passed and came into force in November $2007 .{ }^{42}$ Yet, the law has not declared child marriages to be void, demonstrating the influence of the emotional phenomenon of the sanctity of the institution of marriage. Another glaring example is furnished by the first amendment to the Constitution of India where the framers of the Constitution did not hesitate to trade off the passion for rights with the idea of social justice while inserting the Ninth Schedule in the Constitution. ${ }^{43}$

\footnotetext{
34 Bachan Singh v State of Punjab (1980) 2 SCC 684 [213-215].

35 Maneka Gandhi v Union of India (1978) 1 SCC 248.

36 Sajjan Singh v State of Rajasthan (1965) 1 SCR 933.

37 See The Constitution of India Part IV A (introduced by the 42nd amendment).

38 The Constitution of India art $51 \mathrm{~A}(\mathrm{~g})$.

39 The Constitution of India art 51A(e).

40 The Constitution of India art 51A(a), (b).

41 Although the emotion of love does not reflect in the text of the Constitution, D Y Chandrachud J has recognised the right to love drawing on the value of human dignity. Navtej Singh Johar v Union of India (2018) 10 SCC 1 [352, 384, 477]. For textual recognition of the emotion of love in the Constitution, see the Preamble of the Constitutions of Philippines and Turkey.

42 See generally Jaya Sagade, Child Marriage in India- Socio-legal and Human Rights Dimensions (Oxford University Press 2012).

43 The Constitution (First Amendment) Act 1951.
} 


\subsection{Delimiting the law and emotion rubric}

Due care has to be taken to delimit the universe of law and emotion to guard against undue overlaps. Thus, the extensive analysis or studies dealing with hate crimes may not necessarily represent the field of law and emotion, lest the same does not also analyse the distinctively emotional components of hate, say, against persons with disabilities. ${ }^{44}$ Similarly, it is erroneous to characterise every potentially law-relevant operationalisation of emotion as a part of this scholarship. Thus, the conclusion that judges assign no weight or relevance to the testimony of disabled victims may be the outcome of a study, but the same would be characterised as law-and-emotion scholarship only when the said conclusion is informed by the emotions of sympathy and pathology and is recorded as a substantive part of the study. Thus, even though prima facie the research may be pertaining to law, it should be influenced by nonlaw discourse and scholarship.

\section{Maroney's six-pronged formulation}

In this section, I draw on the six-fold formulation of Maroney in his very influential Chapter ${ }^{45}$ for conceptualisation of law and emotion study and situate it in the context of disability to generate systematic generation.

\subsection{Emotion-centred approach}

This approach involves the analysis of how emotion with its varied theoretical dimensions is reflected in the law. To illustrate this approach, Maroney directs attention at the analysis of the relationship of disgust and law by scholars. Nussbaum attributes to the conception of disgust, the problematic foundation of contamination and disease, demonstrating how its deployment by law has made it anti-social and dehumanising. ${ }^{46}$ On the other hand, Kahan takes exception to the liberal critique and advocates for properly directed disgust for the inculcation and internalisation of equality, solidarity, and other progressive values. ${ }^{47}$ According to Kahan, a refined and modern refurbished conception of disgust is 'indispensable to a morally accurate perception of what's at stake in the law. ${ }^{48}$ The same is aptly illustrated by Article 17 of the Constitution of India abolishing 'untouchability' abruptly,

\footnotetext{
44 See generally Mark Sherry, Disability Hate Crimes: Does Anyone Really Hate Disabled people? (Taylor and Francis 2010); Mark Sherry et. al., Disability Hate Speech: Social, Cultural and Political Contexts (Taylor and Francis 2020); David Wilkin, Disability Hate Crime: Experiences of Everyday Hostility on Public Transport (Springer International Publishing 2020).

45 Maroney, 'Law and emotion' (n 7).

46 Martha Nussbaum, "Secret Sewers of Vice": Disgust, Bodies, and the Law' in Susan A Bandes (ed), The Passions of Law (New York University Press) 23-62.

47 D M Kahan, 'The Progressive Appropriation of Disgust' in Bandes (ed), The Passions of Law (n 46) 63-79.

48 Ibid.
} 
thereby constitutionally conveying disgust for the caste system and artificial social hierarchy. However, the Indian Constitution also deploys disgust, problematically in Nussbaum's sense, to dehumanise and depersonalise persons with unsound minds by making them ineligible to hold public offices. ${ }^{49}$ Thus, the appropriation of the Kahanian progressive conception of disgust is very timely to undo the inhibition in the enjoyment of freedoms and fundamental rights by PWDs.

The resembling emotion of shame is also the focus of attention in the scholarship of law and emotion. It is illustrated in the judgment of the Supreme Court of India in Navtej Singh Johar v. Union of India,${ }^{50}$ where the Court has virtually shamed the indiscriminate sanction against all forms of homosexuality by declaring Section 377 of the Indian Penal Code to be unconstitutional. However, the same court bluntly overlooked this morally refurbished connotation of shame with its refusal to intervene in deciding the constitutionality of the law prohibiting leprosy-cured persons from holding membership of local and self-government bodies. ${ }^{51}$ Shaming the public appearances of PWDs is also very vividly illustrated by enacting the so-called ugly laws. ${ }^{52}$

However, in another judgment of the Supreme Court of India, Justice Sikri linked disgust and shame to combat the prejudice against PWDs by observing:

"Non disabled people do not understand disabled ones." For, non-disabled people generally look upon disabled ones with pity. [...] However, what they do not understand is the feeling of the people with disabilities. Disabled people no longer see their physical or mental limitations as a source of shame or as something to overcome in order to inspire others. ${ }^{53}$

Similarly, a negative reflection of the emotion of fear in law is evident in the indiscriminate institutionalisation of people with mental disabilities. ${ }^{54}$ To prevent the socalled fear in terms of potential danger to the society is often a rationale underlying laws imposing coercive treatment, medication, and shock therapy on PWDs. In my opinion, certain judges of the Supreme Court of India, while holding blindness to be a hindrance in the process of adjudication, were guided by their subconscious fear and prejudice against impairments, and they did not hesitate to translate the same as

\footnotetext{
49 These disqualifications are incompatible with Article 29 of UNCRPD and also contrary to ratification obligation of India under Article 4 of UNCRPD. We have to be careful in distinguishing between people with mental illness and person with unsound mind as the overemphasis on the element of unhindered decision-making smacks off drawing on the 'medical model' and falls fowl of emotional dignity. Soumitra Pathare 'Does Indian Law Disqualify People with Mental Illnesses from Voting?' (The Wire, 5 April 2019). https://thewire.in/health/mental-illness-right-to-vote. Accessed 19 October 2021.

50 Navtej Singh Johar v Union of India (2018) 10 SCC 1.

51 Union of India v Devendra Kumar Pant (2009) 14 SCC 546.

52 See Susan Schweik, The Ugly Laws: Disability in Public (History Of Disability) (New York University Press 2009).

53 Jeeja Ghosh v Union of India (2016) 7 SCC 761 [44].

54 Another noted scholar Cass Sunstein has provided book length analysis of the impact of collective and individual fear on legal regulation. Cass R Sunstein, The Laws of Fear: Beyond the Precautionary Principle (Cambridge University Press 2005).
} 
a legal norm to justify the wholesale exclusion of a particular social group from the domain of judging. ${ }^{55}$

It is submitted that the law must take cognizance of the specific experience of fear and the reactions caused in the context of domestic violence and sexual abuse against women with disabilities; ${ }^{56}$ whereas in reality, by going for the hysterectomy of mentally disabled women, their families aggravate their vulnerability as they may be perceived as objects of free licence for sex by their family members. ${ }^{57}$

The emotions of affection and motherly love have also attracted a great deal of attention from the Supreme Court of India in its landmark pronouncement of Suchita Srivastava v. Chandigarh Administration. ${ }^{58}$ The Court opined that even 'mentally retarded' women can bear and care for their children and could not have been denied the right to self-determination and reproductive autonomy under the doctrine of the best interest of the child. ${ }^{59}$

Focus on a particular emotion facilitates cohesive analysis, as illustrated above. However, in the absence of a consensus on the definition of emotion, we have to ask ourselves whether inadequacies in defining emotion would inhibit the emotioncentred approach or can we do well by merely relying on the various approaches to the relationship of law and emotion? Maroney has aptly illustrated the dilemma by asserting whether 'passion of justice' is a distinct emotion in a psychological or neuroscientific sense or is it a law-relevant phenomenon from the perspective of moral philosophy and legal theory that may always remain an unresolved issue. ${ }^{60}$ It is not possible to take any definitive position on this issue, as the paper is an evolutionary meditation.

\subsection{Emotional phenomenon approach}

Though prima facie, this approach resembles the previous approach; however, the primary focus of the latter is a mental process or behaviour recognising the vital role of emotion, but the same being itself not an emotion; whereas, the former directly engages with emotions rather than focusing its attention on mental processes and behaviours implicating emotions.

Comprehension of emotion-driven phenomena as distinct from the emotions that are its subjects is an analytical headway. ${ }^{61}$ An obvious example is the impact of empathy while exercising mercy or pardoning power in the context of public law. ${ }^{62}$ A noted philosopher, Henderson, conceptualises empathy not as a distinct emotion

\footnotetext{
55 V Surendra Mohan v State of Tamil Nadu (2019) 4 SCC 237.

56 Patan Jamal Vali $v$ The State of Andhra Pradesh 2021 SCCOnLine SC 343.

57 In the United States (US), Justice Holmes in the US Supreme Court has advocated the sterilisation of mentally disabled. Paul A Lombardo, Three Generations, No Imbeciles: Eugenics, The Supreme Court, and Buck v. Bell (The Johns Hopkins University Press 2008).

58 Suchita Srivastava v Chandigarh Administration (2009) 9 SCC 1.

59 Ibid.

60 Maroney, 'Law and emotion' (n 7) 544.

61 Ibid. 545.

62 See Article 72 of Constitution of India.
} 
but as a mechanism through which the emotions of others are appreciated and processed. ${ }^{63}$ Under this approach, scholars are expected to carefully expound both these aspects, a feat difficult to accomplish and therefore many authors do not agree with the same. ${ }^{64}$

The difficulty compounds because several psychological phenomena intertwine emotions. The same has the potential of category erosion due to its extraordinary expansion making it difficult, if not impossible, to understand a particular emotion in relation to the other. Without getting into any debate, I endorse Maroney's view that only those phenomena that dominantly intertwine emotions are a part of this scholarship. The obvious example of an emotional phenomenon is affective forecasting, i.e., prediction of the future emotional state, whereas selective attention on emotions through a phenomenon is not the case of emotional phenomenon. ${ }^{65}$ The analysis of legal consequences of the former is an example of law-and-emotion scholarship. On the other hand, the latter can be tagged as a part of this scholarship only if directed against the emotion question.

Since predictability is one of the key virtues of law, it may be used to forecast future emotions. However, in the context of disability, the judges often prefer their own a priori assumptions to affect the predictability of the law. Thus, the Madras High Court, while characterising the appointment of blind persons as judges as avoidable complications, virtually changed the norms of the qualifications and held that only persons with 40-50\% sight could be considered for the appointment of judges in lower courts. ${ }^{66}$ The Supreme Court went a step further by complaining that blind persons are unfit as judges because they cannot maintain confidentiality. ${ }^{67}$ In my opinion, since the law is predicated and directed at the attainment and fulfilment of interests of the typical, under the influence of ableism, judges are obligated to invoke emotional phenomenon like 'Constitutional Morality' and 'Transformative Constitutionalism' to infuse the law with the values and emotions of inclusion, full participation and respect for difference of PWDs in the light of ratification of UNCRPD by India. The infusion must take the shape of a predictable pattern during the interpretation and adjudication of the ableist law.

\subsection{Theory of emotion approach}

This approach is driven by theories of emotions, and posits an analysis of the impact of such theories on the law. Varied accounts of etymology, elements, nature, functioning, and purpose of emotion should not be considered a disincentive for acceptance and application of this approach. A careful exposition of the same may render valuable teachings about the law. In order to conduct any study on the relationship

\footnotetext{
63 Lynne Henderson, 'Legality and Empathy' (1987) 85 Michigan Law Review 1579-80; Justin D’Arms, 'Empathy and Evaluative Inquiry', (2000) 74(4) Chicago-Kent Law Review 1479.

64 Ibid.

65 Maroney, 'Law and emotion' (n 7) 544, 545.

66 V Surendra Mohan $v$ State of Tamil Nadu (n 55).

67 Ibid.
} 
of law and emotion, it is imperative to determinatively provide one's choice about the operative theory/theories of emotions and reasons for preferring the same over other competing theories.

Thus, when a judge undermines the ability or questions the capability of PWDs because of the prevalence of the stigmatised image of the concerned disability, PWDs must theorise their account of emotions around such a disability cohesively. Un-accounting the same would generate uncertainty. Similarly, while devising remedies for the emancipation of PWDs, the law must hint at a particular theory of emotion, i.e., promoting dignity or problematising the ableist construction. Let me illustrate this approach by briefly discussing one of the interesting theories of emotions evolved in light of disability and aesthetics.

\subsubsection{Disability aesthetics}

In an influential article, Jasmine E. Harris ${ }^{68}$ has convincingly argued against uncritical adherence to the notions of non-discrimination and contact hypothesis as key strategies for the empowerment of PWDs. Harris pinpoints the flaws of the conventional models of disability discrimination preventive remedies. In the context of the relationship of law and emotions, her views deserve attention; unsentimental disability legal theories fail to account for how 'the aesthetics of disability predicate rights and the integrative ideal.' 69 'The aesthetics of disability are visible sensory and behavioural markers that trigger particular aesthetic and affective judgments about marked individuals.' 70 Thus, taste in body and mind, inclusive of behavioural patterns being considered as individual predilections, is deemed to be outside the purview of legal intervention. For example, whether one would like to have lunch or dinner in the company of her disabled colleague would be a matter falling outside the regulation of service conditions being based on personal taste.

We overlook how appearances, perceptions, and feelings anchor the access to rights and privileges in every sphere of life and affect our conduct. The aestheticaffective process does not have mere somatic dimensions but is also contingent on the social-cultural milieu. The aesthetic markers, like the colour of the body, height, shape and size and other atypical differences, are determinative of the degree of success and enjoyment of rights and privileges and the extent of social control. Matters like abortion of a foetus, ${ }^{71}$ the degree of care and attention received by the patient, ${ }^{72}$

\footnotetext{
68 Jasmine E Harris, 'The Aesthetics of Disability' (2019) 119(4) Columbia Law Review 895-972.

69 Ibid. 2.

70 Ibid.

71 Smitha Nizar, The Contradiction in Disability Law: Selective Abortions and Rights (Oxford University Press 2016); Sofia Yakren, "Wrongful Birth" Claims and the Paradox of Parenting a Child with a Disability' (2018) 87 Fordham Law Review 583.

72 During the COVID-19 Pandemic in 2020, in the guise of rationing the beds, or providing lifesaving drugs, PWDs have been given very low priority, even in richest country like the US.
} 
employment opportunities, ${ }^{73}$ etc., are contingent on the aesthetic markers. In my opinion, the criteria of suitability for availing certain jobs by PWDs are nothing but aesthetic markers. The appearance does not merely intrude on visible disabilities but equally affects invisible disabilities too. Thus, multiple sclerosis or dyslexia being invisible are not perceived as disabilities. ${ }^{74}$ Overlooking the combination of physical disability and social disability, i.e., Scheduled Caste/Scheduled Tribes, disabled women may also thwart the detection of an invisible aspect of disability due to the intersection between the two. This point is crucial in the Indian context. Thus, in Patan Jamal Vali v. The State of Andhra Pradesh, ${ }^{75}$ even though the prosecution did not make a case under the Scheduled Caste and Scheduled Tribes (Prevention of Atrocities) Act 1989, the Court could have interpreted Article 21 of the Constitution of India through the lens of intersectionality. Justice D. Y. Chandrachud indeed infuse the discourse with intersectionality, but his reluctance to transpose the same as a part of remedy made the whole exercise a missed opportunity. Full throated infusion of intersectionality in the concept of disability-based discrimination would have produced law and emotion synergy with empathy at its core.

It is, therefore, important to pay attention to the anchoring of aesthetics and aesthetics-affective emotions. Even in the absence of any clear distinction in cognitive capacity, aesthetics and emotions seldom account for an assessment of competence. Such an account also has a bearing on an individual's moral, ethical and existential standing in society. Aesthetic judgments can implicate both the enactment of laws as well as their interpretation and adjudication. Without explicit reference to aesthetics, I have already pinpointed the judicial pronouncement pertaining to the appointment of blind judges and will demonstrate below the problematics of Section 3 of RPwD Act.

Jasmine invites our attention to an emerging subfield under aesthetics called 'everyday aesthetics,' applying the concept of taste to everyday objects rather than art, per se, thereby implicating individuals and their bodies. ${ }^{76}$ Although, as a matter of principle, collective taste in bodies is not static, its dynamism in national, ethnic, and cultural settings is markedly affected by technological advancement and connectivity, thereby rendering it homogenous. ${ }^{77}$ Although fatness, per se, is not the objective determinant of bad health, the society invariably attaches negative connotations to the same by identifying thinness as a positive marker of good health. Societal aesthetic obsession about thinness is stretched so far as to overlook eating disorders like bulimia or anorexia as if a thin body and being healthy are synonymous. From a critical perspective, we cannot solely locate thinness in the body to exclude its

\footnotetext{
73 The best example is the legal mandate for identification of suitable jobs for PWDs and reservations for PWDs. See The Rights of Persons with Disabilities Act 2016, Act No. 49 of 2016 ss 33, 34 which relate to 'identification of posts for reservations' and 'reservation' respectively.

74 For example, a patient with Type 1 Diabetes requires expensive medication and has to wear highly expensive pump to maintain the insulin level, nevertheless the same is not regarded as Disability in India.

75 Patan Jamal Vali v The State of Andhra Pradesh (n 56).

76 Harris, 'The Aesthetics of Disability' (n 68) 13.

77 Ibid.
} 
socio-cultural construction and must also reflect how like race and caste, it can be deployed to oppress marginalised and vulnerable populations.

Connoting its nuances, Jasmine demonstrates that disability aesthetics in particular and aesthetics, in general, are not merely structural but also play a vital role in

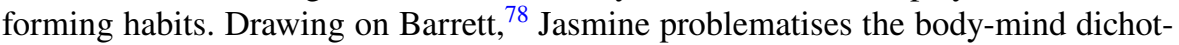
omy around classical theory of emotions to establish the same. ${ }^{79}$ According to the classical theories of emotions, expressions are biologically based and universally recognized. ${ }^{80}$ However, under the newly emerging theories, it is anachronistic to view emotions like anger and disgust as inborn or genetic fingerprints; rather, they must be perceived as learned. ${ }^{81}$ In other words, emotions are to be seen as an outcome of habit rather than as an innate phenomenon. To quote Jasmine, 'In sum, our brains are predictive, and not reactive, to the senses. ${ }^{82}$

\subsubsection{Disability aesthetics and the Indian Constitution}

In this light, let me take this discussion on a practical plane and investigate how the emotion of disgust is evoked. Often, we tend to look with disgust at certain individuals (like PWDs) under the affective influence that interaction with them would increase the risk of contamination and harm. Our disgust for PWDs is socially and culturally determined and guided by structural and habitual aesthetics. The feeling of disgust with its lingering property of prejudice tends to dissuade the so-called 'typical' from interacting with 'atypical.' Similarly, the feeling of contempt is based on the assumption that somebody is a lesser human being or unproductive. The lingering effect of emotions of disgust and contempt is evident in the Constitution of India. It explicitly prohibits persons with unsoundness of mind from assuming public offices of the President of India, the Prime Minister, parliamentarians, and ministers. ${ }^{83}$ Even the inclusion of a person in the voter's list of an electoral constituency

\footnotetext{
78 Lisa Feldman Barrett, How Emotions are Made: The Secret Life of the Brain (2017).

79 Harris, 'The Aesthetics of Disability' (n 68).

80 Azim F Shariff and Jessica L Tracy, 'What Are Emotion Expressions For?' (2011) 20 Current Directions in Psychological Science 395, 397.

81 Joseph E LeDoux and Richard Brown, 'A Higher-Order Theory of Emotional Consciousness' (2017) 114(10): E2016-E2025 Proceedings of the National Academy of Sciences of the United States of America 7.

82 Ibid.

83 The Constitution of India art 102, 191, 326. The membership of Parliament or State legislature is a pre-condition for assuming the offices of the President and Vice President, Prime Minister, Chief Minister, and any other minister. Therefore, a person with unsound mind is ineligible for the appointment of the above offices. The comparison between Articles 102, 191 and Article 326 is interesting. Under the former, the unsoundness of a person has to be determined by a court of law before the trigger of disqualification, whereas Article 326 while imposing said disqualification has to be read with Section 16 of the Representation of the People Act 1950, Act No. 43 of 1951, which replicates Article 102. Curiously, neither the Code of Civil Procedure 1908 nor the Code of Criminal Procedure 1973 provides a procedure to determine the unsoundness of mind of a person. Even the RPwD Act is silent on this point. In absence of a rule-bound regime, courts in India rely on their own hunch or the English common law to determine the unsoundness of mind. It is also not clear whether there is any distinction between unsoundness of mind and insanity/lunacy.
} 
is contingent on having 'soundness of mind'. ${ }^{84}$ Both the Supreme Court and High Courts judges can be removed from their positions on the ground of, inter alia, incapacity. ${ }^{85}$ The term 'incapacity' appears to be loaded in the absence of adequate explanation and sounds ableist. Article 317(3)(c) empowers the President to remove the Chairman or any other member of a public service commission from office if, in the opinion of the President, the Chairman or such member is unfit to continue in office by reason of infirmity of mind or body. This clause readily demonstrates public contempt for disability. ${ }^{86}$ Compounding the same, the constitutional topography very awkwardly sandwiches Entry 9 List II (State List) 'Relief of the disabled and unemployable' between Entry 8 'Intoxicating liquors...' and Entry 10 'Burials and burial grounds; cremations and cremation grounds.' The placement of disability in such an indifferent and insensitive manner speaks volumes about the blunt State consciousness about the disabled in particular, and vulnerable sections of society in general. Equally, it should be noted that the word 'disabled' is prefixed by 'relief of' and suffixed by 'unemployable,' thereby providing very little room for legislative manoeuvring. In a way, the word 'disabled' is again sandwiched between relief and unemployable as if only for providing relief and addressing unemployment, the legislature is obligated to make laws.

\subsubsection{Paradox of Articles 41 and 46 of the Indian Constitution}

The above argument is further reinforced by the language of Article 41, a Directive Principle of State Policy ${ }^{87}$ which reads, 'The State shall, within the limits of its economic capacity and development, make effective provision for securing the right to work, to education and to public assistance in cases of unemployment, old age, sickness and disablement, and in other cases of undeserved want.' This provision is a textbook example of how Constitutions are confluence by ableism. In a very ambivalent and condescending tone, the disablement is stationed in the Constitution alongside unemployment, old age, and sickness and on the other hand, while mandating the State to make effective provisions for securing the rights to work, education and public assistance, the obligation is watered down by giving a long rope through the conditionality, 'within the limits of its economic capacity and development.'

A careful reading of this article alongside Entry 9 List II very glaringly establishes that the Constitution of India has conferred less than a second-class citizenship status on the PWDs. Categorically, the text of the Constitution continues to perpetuate an abhorrent and embarrassing idea that PWDs deserve certain rights only if affordable to the State. The flip side of this proposition is that only affordable claims brought by PWDs on the ground of disability-based discrimination should be entertained.

\footnotetext{
84 The Constitution of India art 326.

85 The Constitution of India arts 124(4), 217(1).

86 This is a unique provision invoking the categorical Presidential Powers.

87 The Constitution of India art 41, provides for 'Right to work, to education, and to public assistance in certain cases.'
} 
To contrast the constitutional indifference and neutrality towards PWDs to that of the Scheduled Castes and Scheduled Tribes, Article $46^{88}$ is worth reading: 'The State shall promote with special care the educational and economic interests of the weaker sections of the people, and, in particular, of the Scheduled Castes and the Scheduled Tribes, and shall protect them from social injustice and all forms of exploitation.' There are stark differences between these two Articles. Unlike the former, the latter is not subject to the limits of economic capacity and development of the State, nor does it sound paternalistic. On the other hand, apart from being subject to the conditionality of limits of economic capacity and development of the State, the former treats disablement as the lowest priority ${ }^{89}$ by even insulating the same from the weaker sections of people as if the Constitution aspires to recognise disablement as luminal alterity. The language of Article 46 justifies this argument intrinsically with the recognition of a category of 'weaker sections of the people' but excluding from its scope disablement and recognising the Scheduled Castes and Scheduled Tribes as its constituents.

The Preamble of the Constitution of India employs the expression 'We the people,' and Article 46 slightly modifies it by laying down weaker sections of the people. If the word 'people' in the Preamble were to be inclusive, then is it not possible to critique the exclusion of disablement or disability from the resembling expression 'weaker section of the people' under Article 46? It is a moot question. However, it is interesting to note that although both the articles operate on an aspirational plane as part of Constitutional ethics, the exclusionary nature of Articles 46 and 41 generate a strange constitutional paradox trading off priority of the disabled with weaker sections of the people.

The above discussion makes a case for revisiting Article 41 and instilling it with emotions of dignity and empathy to bring the disabled at par with other weaker sections. To quote András Sajó,

A proper consideration of the emotional components of law is important for a descriptive theory of law, but this does not presuppose or demonstrate that moral emotions and hence moral precepts determine legal rights, only that there is some correspondence between some rights and other binding institutional regimes. A weak correspondence is enough to give emotional and social credibility to the rights-and-duties-based system that we call modern law. ${ }^{90}$

\footnotetext{
${ }^{88}$ The Constitution of India art 46, provides for 'Promotion of educational and economic interests of Scheduled Castes, Scheduled Tribes and other weaker sections.'

${ }^{89}$ Ron Amundson has critiqued the academic tendency to attach lesser value to disability rights compared with women or racial minorities. Ron Amundson, 'Disability Rights: Do We Really Mean it?' in D Christopher Ralston (ed), Philosophical Reflections on Disability (Springer Publication 2010).

90 András Sajó, 'The Constitutional Domestication of Emotions' in Sellers (ed) Law, Reason, and Emotion 554 .
} 


\subsubsection{Paradox in UNCRPD}

Let me briefly extend the same enquiry to investigate the relationship of law and emotions in the context of UNCRPD with a special focus on equality. The entire UNCRPD is constructed on a paradox - on the one hand, in its Article 3(d), the Convention provides that PWDs constitute a form of 'human diversity and humanity,' and the same is also reinforced by the Preamble emphasising 'overall well-being and diversity of their communities.' In a similar vein, paragraph 'm' of the Preamble seeks to promote 'the full enjoyment of human rights and fundamental freedoms and full participation by persons with disabilities entailing in their enhanced sense of belonging and in significant advances in the human, social and economic development of society and the eradication of poverty. ${ }^{91}$ In the context of the right to equality and non-discrimination, Article 5 is categorical in recognising, promoting, protecting and fulfilling the values of 'equality before law,' 'equality under the law,' "equal protection and benefit of law.' 92

However, on the other hand, Article 1 provides that the purpose of the present Convention is 'to promote, protect and ensure the full and equal enjoyment of all human rights and fundamental freedoms by all persons with disabilities, and to promote respect for their inherent dignity [...] on an equal basis with others.' 93

In my opinion, there is a tension between Article 3(d), the clause 'm' of the Preamble, Article 5(1) and Article 1 of UNCRPD. The goal appears to be to achieve brotherhood through the means of otherhood. Thus, the benchmark being otherhood and the terms such as equality, brotherhood, humanity being emotion-laden concepts are predicated by an ableist paradigm. The same raises the fundamental question, whether PWDs are same or different from others. But the terms 'same and different' are also emotionally laden. In order to fully grapple with this tension, it is necessary to critique Article 1 through the lenses of ableism, disablism and law and emotion to expose their ableist connotations and inform the same with the lived experiences of PWDs.

A careful examination of the language of UNCRPD makes it evident that it has espoused the comparativist conception of equality by the repeated deployment of the phrase 'on an equal basis with others.' 94 More or less, even the Convention on the Elimination of all Forms of Discrimination Against Women (CEDAW) adopts the comparativist conception of equality by harping on the notion of on the basis of equality of men and women. ${ }^{95}$

UNCRPD and CEDAW, to sound logical, have adopted the benchmarks of ableism and men for attaining formal equality. However, such a notion of equality being parasitical on other values for its crystallisation has to be informed by and sensitive to the public emotions of compassion, dignity and respect for difference.

\footnotetext{
91 UNCRPD, The Preamble.

92 UNCRPD art 1(1).

93 Ibid.

94 This phrase 'on an equal basis with others' appears 31 times in the UNCRPD.

95 The term 'equality' appears 22 times in the CEDAW.
} 
Thus, the axiom that the disabled be treated like able-bodied would sound extremely formal and crude, in the absence of centrality to the difference and overemphasising the benchmark of ableism; much, therefore, would depend on the purchase state parties have on the phrase 'on an equal basis with others.' Thus, a question arises, how a state party should capture the purchase, how it should interpret the aforementioned phrase to incorporate it as a part of its legal order.

The feeling of treating human beings with dignity has an immense value in attaching intrinsic worth to every person irrespective of differences and to problematise instrumental gradation of the beings by harping a particular ideology. Its repeated assertion in the company of compassion and empathy has the potential to evolve a positive disability aesthetic abandoning 'typicality' and embracing 'atypicality' and non-normativity. It is not possible to fully explore these ideas in this short article nor the author claims any cohesive theorisation of the same and would like to join the queue for more meditation.

A careful look at the aforementioned discussion demonstrates an unease in the legal order to recognise PWDs as full human beings. Moreover, under the lingering impact of moral disgust and contempt, lawmakers may find it extremely difficult to abandon pathways marked by stigmatisation and stereotypes of PWDs.

\subsubsection{Disability aesthetics and emotions}

Disability aesthetics and emotions are driven by habits and capable of generating prescriptive guidance; norms arising from such guidance are extremely entrenching. Jasmine rightly points out, 'An individual's aesthetic sensibilities are difficult to shift through cognitive reasoning. ${ }^{96}$ The repulsions arising out of these norms have the potency to rewrite and reinterpret the Constitution and legislations as evidenced by the judgment in $V$. Surendra Mohan by the Supreme Court of India and the critique of Article 41 of the Constitution of India. ${ }^{97}$

From the above discussion, I can establish very clearly, the sentimental bias of public law rooted in the emotions of disgust and public contempt for PWDs. Sentimental bias attached to appearance in particular and other negative emotions about PWDs cannot be done away merely with the imposition of the duty not to discriminate. Moreover, raising awareness about disability or PWDs mandated by Article 8 of UNCRPD may sound extremely platitudinous and paternalistic viewed uncritically. The same also translates into the drafting processes of laws, e.g., the RPwD Act mediating rights of PWDs mostly through power-conferring rules rather than through the enactment of right-conferring provisions in favour of them. The rationale underlying such a procedure is to reinforce the incompetence and lack of agency of PWDs unwittingly. Thus, aesthetic affective norms echoed in collective taste in bodies would render a blunt classical anti-discrimination regime and would look at awareness, education and retraining, with blinkers.

96 Harris, 'The Aesthetics of Disability' (n 68). (Internal citations omitted).

97 V Surendra Mohan $v$ State of Tamil Nadu (n 55). 
In order to make the legal system just and favourable to PWDs, it is necessary to expose disability aesthetics even in the so-called disability empowering legislation, for e.g., RPwD Act. Thus, to illustrate, while empowering the State to exempt fully or partially any establishment from its purview, it does not subject this power to the conditionalities of Section 3, i.e. non-discrimination on the ground of disability. ${ }^{98}$ By using the proxy of the independence of judiciary, the Bombay High Court purported to exempt the judiciary from the purview of RPwD Act while refusing to implement reservations in jobs for PWDs in its administrative wing. ${ }^{99}$

It is very easy for employers to frustrate the employment opportunities of PWDs by firing them during the probation period under the influence of disability affective emotion of incompetency. ${ }^{100}$ Often, PWDs are undermined during the interview process by negatively targeting their disabilities in the assessment and interaction. Thus, it is extremely common for a blind person applying for the position of a teacher to expect repulsion from the interview body with questions like how do you use the blackboard? Would lack of eyesight or eye contact not affect your ability of class control?

There is a very interesting judgment of the Supreme Court of India detailing the embarrassment meted out to a teacher with cerebral palsy by the Jammu and Kashmir High Court. ${ }^{101}$ The judges of High Court did not hesitate to superimpose themselves as evaluators to test the competence of a teacher with cerebral palsy, throwing in doubt his previous selection by a competent statutory body. ${ }^{102}$ Surprisingly, the wise judges declared the said teacher to be disqualified, thereby perpetuating, and enduring their taste in collective bodies and reinforcing the societal misunderstandings and disgust about people with cerebral palsy. Fortunately, the Supreme Court took a strong exception to the approach of the High Court, but in terms of theorising the discourse from the lens of law and emotion, the pronouncement was a missed opportunity. ${ }^{103}$

\footnotetext{
98 Although under proviso to Section 34 of the RPwD Act, the appropriate government is required to consult chief commissioner or State commissioner as the case may be before providing exemption to any establishment from the provisions of this section (i.e. obligation to provide $4 \%$ reservation). Yet, the recent examples of exemptions are contrary to the mandate of this proviso. Unfortunately, the proviso to Section 20 of the RPwD Act empowering the appropriate government to exempt establishments from its provisions (i.e. non-discrimination in Employment) dispenses with requirement of consultation with Chief commissioner or state commissioner as the case may be; some recent examples of exemptions are quite to the contrary. Anju Maskeri, 'Don't Want a Pedestal, Give Us Equal Opportunities: Disability Activists' (Mid-day, 12 September 2021). https://www.mid-day.com/sunday-mid-day/article/dont-wanta-pedestal-give-us-equal-opportunities-disability-activists-23191953. Accessed 19 October 2021.

99 National Federation of Blind v The High Court Judicature of Bombay 2018 SCCOnLine Bom 931 [20-29].

${ }^{100}$ Sanjay Jain, 'Some Reflections on Disability Based Discrimination and Denial of Reasonable Accommodation to Persons with Disability in Employment' (2013) 4 Gender, Human Rights and Law $157-177$.

101 Syed Bashir-ud-din Qadri v Nazir Ahmed Shah (2010) 3 SCC 603.

102 Ibid.

103 Ibid; For critical analysis, see Sanjay Jain, 'Disability Rights at a Crossroads: Reflections on Evolution of Public Law of Physical and Mental Disability' in M.P. Singh (ed), The Indian Yearbook of Comparative Law (Oxford University Press 2016) 370.
} 
Although the RPwD Act ${ }^{104}$ and UNCRPD emphasise community-based rehabilitation of PWDs, the disability-affective culture makes it extremely difficult for parents to up-bring their disabled children in an environment, that is stigmatising and sometimes even hostile for the PWDs. The same is very vividly illustrated in a 1990 Indian Tamil-language film titled 'Anjali' which concerns a mentally disabled child's interaction and encounters with the society.

Aesthetic discomfort of the Court may result in the infraction of fundamental rights by the PWDs. In Eera Kumar v. State (NCT of Delhi), ${ }^{105}$ the Supreme Court confused the disability of the rape victim by collapsing the distinction between intellectual disability and cerebral palsy. The Court also did not find it appropriate to examine the question of whether she was entitled to age-appropriate accommodation from the standpoint of constitutional compassion and renaissance. ${ }^{106}$ It was a fit case to fill the legislative vacuum in procedural justice in the trials involving disabled rape victims. The Supreme Court conceived the idea of a constitutional renaissance by observing,

It is to remain in a constant awakening as regards the text, context, perspective, purpose and the rule of law. Adherence to rationality, reverence for expected pragmatic approach on the bedrock of the constitutional text, context and vision and constant reflection on the valid exercise of the power vested tantamounts to resurgent constitutionalism. ${ }^{107}$

\subsubsection{Suspicious bodies}

Which bodies must be subordinated, penalised, stigmatised or abused, is often actuated by the considerations of disability aesthetics. It is very common to look with suspicion at individuals with non-normative appearances. The same is very cogently echoed in clause 4 of Section 3 of RPwD Act discussed below. ${ }^{108}$

The law and emotions scholarship is deeply ableist. In some legal systems, claims of wrongful birth and life are sustained as part of emotional distress. The same are brought by the parents of the disabled children and the disabled children themselves, respectively, as if the disabled person is a lesser human being, aggravating the emotional trauma of parents and self. Such unquestioned assumptions about the substandard pattern of lives of PWDs, apart from being unscientific, are also unethical and perpetuate the negative emotion of shame and devaluation. As the status of able-bodied-ness is contingent on several factors - political, social, economic, and

\footnotetext{
104 See The RPwD Act s 6, pertains to 'protection from cruelty and inhuman treatment.'

105 Eera v State (NCT of Delhi) (2017) 15 SCC 133; See Arushi Garg, "Navigating Through "Age" and "Agency" in Eera v State' (2018) 14 Socio-Legal Review 79.

106 Upendra Baxi, 'A Constitutional Renaissance' (The Indian Express, 16 July 2018). https://indianexpr ess.com/article/opinion/columns/a-constitutional-renaissance-indian-judiciary-delhi-lg-powers-5260959/. Accessed 14 June 2021.

107 Government of NCT of Delhi v Union of India \& Anr (2018) 8 SCC 501 [280].

108 Section 3(4) of the RPWD Act states that 'No person shall be deprived of his or her personal liberty only on the ground of disability.'
} 
physical, etc., - we should be wary of indulging in the processes of 'othering' based on artificial hierarchy. Drawing from a noted philosopher Goffman ${ }^{109}$, Nussbaum observes, "there is a public fiction that a sharp line divides the "normal" from the stigmatized; in reality, the normal and the stigmatized are a part of one another. 110 Thus, the fiction of an independent adult, a version of fiction of perfection is deployed as a vehicle to exclude, alienate, and isolate those with atypical needs as mere straws. The emotional phenomena of empathy can be theorised and evolved to rewrite the Constitutions and the laws to earnestly challenge the ableist crudity in forming the social contract, and revitalising fraternity and dignity by emphasising the intrinsic worth of every human being — disabled or non-disabled-in light of dignity. The way forward is to reconfigure the classical anti-discrimination law through the insights drawn from disability aesthetics along with challenging sensory and behavioural markers about disabilities in law. The law as an institution has to be emancipated from disability-affective norms/emotions and aesthetic values of beauty, effortlessness, and health and be reinfused with public emotions of empathy, compassion, and dignity.

The problem associated with the principle of integration during contact of disabled and non-disabled can be tackled by developing the conception of inclusion sensitive to and attendant upon disability aesthetics and by targeting its negative potency to mediate access to rights by PWDs. Jasmine provides the following prescriptive responses: ${ }^{111}$

a) Attention to facilitating/rights enabling conditions.

b) Emphasis on empirical research for redesigning of institutions.

c) The design of legal remedies be predicated on empirical studies.

d) Using an aesthetic-affective lens could enhance the work of scholars thinking about meaningful access, accommodations, and universal designs.

e) Finally, the focus of disability rights law and policy must be to shift the normate and would require a slow but steady departure from the default to inclusion.

These prescriptions may sound utopian because seldom do laws precede empirical studies. However, if the goal is to liberate the society from the shackles of ableism, then the way forward must be radical and imaginary.

\subsection{Legal doctrine approach}

Unlike the earlier three prongs focusing on the emotion dimension of the 'and', this approach is driven by its law dimension. Under this approach, a particular doctrine of law is identified as a focus for analysing how emotion can be incorporated in the same.

\footnotetext{
109 Erving Goffman, Stigma: Notes on the Management of Spoiled Identity (Penguin Books 1963).

110 Nussbaum, Hiding from Humanity (n 1) 312.

111 Harris, 'The Aesthetics of Disability' (n 68) 24.
} 
One of the obvious illustrations is from the criminal law involving the distinction between murder and culpable homicide not amounting to murder, directing attention to investigate whether a crime was committed in the 'heat of passion' or 'under the influence of extreme mental or emotional disturbance.' ${ }^{112}$ In the context of disability, this approach has vast potential viz. problematising the ableist dimensions of social contract; calling for revision of qualification-based model of human; critiquing exclusionary constitutionalism; fostering respect for difference and human diversity; evolving dignitarian conception of the human, etc.

Nussbaum demonstrates extraordinary empathy about PWDs by recognising their perennial societal subordination and highlights how differential treatment meted out to them is considered appropriate on the ground of natural differences by the Academicians and scholars indignating 'stigmatisation on the basis of race, sex or sexual orientation.' ${ }^{113}$ However, upon closer scrutiny, I find some ambivalence in her aforementioned views because, in the same breath, she also observes, 'In order to make this point that one need not accept the radical thesis that there is nothing bad about the classic disabilities, such as blindness, deafness, and mental retardation' and finds it 'implausible' to take position against prevention or curing of blindness, loss of hearing, loss of motor ability, et cetera.' 114

While very forcefully denouncing the typical/atypical dichotomy, Nussbaum again roundly contradicts herself by observing, 'We may grant that some central functional capabilities are not just typical, but also very useful—good things to have in pursuing a variety of different human plans of life. ${ }^{115}$ Moreover, Nussbaum ventures to exhort,

In so judging, we need take no stand on the contested question of whether these abilities are 'natural' in any value-free sense. Without any such controversial claim, we may say that seeing, hearing, locomotion of the limbs, et cetera, are valuable instruments of human functioning, and thus reasonable things to shoot for in thinking about what a system of health care should promote. They are thus political goods, whether or not they have any particular metaphysical or 'natural' status. ${ }^{116}$

On an emotional plane, the aforementioned views of Nussbaum are nothing less than sophistry. On the one hand, she's wary of taking any position on a vital and contested question of whether a disability is good or bad, and yet, she perceives certain disabilities to be bad and goes so far as to characterise certain abilities like seeing, hearing as 'political goods,' and the said conclusion according to her does not require any determination of whether such abilities are natural or metaphysical. How her conception of disability is completely contingent and half-hearted is borne out from her most telling assertion,

\footnotetext{
112 Indian Penal Code ss 299, 300 which relate to 'culpable homicide' and 'murder' respectively.

113 Nussbaum, Hiding from Humanity (n 1) ch 6305.

114 Ibid. 308.

115 Ibid.

116 Ibid. (Internal citations omitted).
} 
This same way of thinking also implies, however, that if an individual is not able to achieve mobility, communication, and so forth, in the 'most common ways' because of an impairment, society has a particularly urgent set of reasons to (re)design things in the social, educational, and political environments so that those capabilities will be available to that individual. ${ }^{117}$

The terms 'most common ways' need special attention. If a group of PWDs' deprivation of mobility is not implicated by 'most common ways', i.e., if the deprivation results due to certain special reasons having no bearing on common ways, then it is not clear whether Nussbaum would insist on the kind of transformation in the design of the society about which she is so vocal otherwise. The same also casts doubt about her position on the degree and extent of individualisation of accommodations and redesigning. In other words, her reference point for treating PWDs with dignity being an able-bodied man and woman and therefore, she is able to argue that the common ways in which the able-bodied have mobility be redesigned urgently to accommodate PWDs. To put it bluntly, rather than fostering respect for difference and going for categorical assimilation and inclusion of PWDs into the mainstream of society, she advocates accommodation with insistence on the transformation of the most common ways.

While exposing these cracks in Nussbaum's theory, I am against throwing the baby with the bathwater as in many other respects; her views on disability are extremely empowering and progressive. For example, she very rightly exposes the inherent contradictions in Americans with Disability Act of 1990 (ADA) by problematising its disproportionate focus on impairments substantially limiting major life activities. ${ }^{118}$ She is very forthright in condemning the double-speak of law in the context of reasonable accommodation. She rightly asserts that if racial discrimination cannot be condoned on cost considerations, why should the discrimination based on disability be contingent by limiting the obligation of the employers to incur only reasonable costs? She also hits the nail on the head by observing that special costs associated with the implementation of American legislations like ADA and Individuals with Disabilities Education Act 1975 are neither natural nor actuated by 'a presocial difference between the person with a disability and other allegedly nondisabled people. ${ }^{119}$ Rather, the costs have to be incurred because of the biased societal design tilted in favour of the so-called average person, i.e., a non-disabled person.

Nussbaum's critique of the formation of the social contract also clearly testifies distaste for the ableist and perfectionist conceptualisation of the human. She very rightly questions the so-called prioritization of certain normal human needs over asymmetrical or unusual dependency of PWDs. I intend to draw profound insights from her critique of the stigmatising political culture. She very rightly observed that

\footnotetext{
117 Ibid.

118 Ibid. 318.

119 Ibid.
} 
'perfection - self-sufficiency, competence, and (the fiction of) invulnerability' ${ }^{\prime 20}$ conduce stigmatising political culture in respect of PWDs. Although she makes this assertion in respect of the US, it is equally applicable to the rest of the world.

To construct the theory of emotions and law for the empowerment of PWDs, Nussbaum's critique of liberal citizen and the liberal society, along with her clarion call to inhibit the narcissistic perfection, are additional insights. She is also very right in advocating individualised interventions, but alas, they go only so far as the right to be in the world. However, PWDs aspire much more.

Methodologically, the approach of Nussbaum sounds ambivalent. She does not take a categorical position on the conception of disability; rather, by conceptualising the same as a contested question, she unwittingly enters the territory of ad-hocism. I wonder whether avoiding taking a position on a seminal issue of conceptualisation of disability is a commitment to methodological promiscuity in Miller's terms ${ }^{121}$ or a casual position from a theoretical smorgasbord. ${ }^{122}$

The same incoherence is echoed in the provisions of the RPwD Act, which, while advocating a rights-based approach, also, in the same breath, adopts a medical approach to disability by couching the definition of benchmark disability in light of dichotomy of measurable and non-measurable terms, and insisting on the best possible corrections while defining blindness and low-vision. ${ }^{123}$

\subsection{Theory of law approach}

The theory of law approach complements the emotion-theory approach. It focuses on analysing a particular theory of law, e.g., in light of the positivist theory of law the scholars analyse emotions.

Law and economics rubric prominently represents this approach. Factoring emotions in rational choice is regarded as a malady, and therefore, directs action and attention against the same. ${ }^{124}$ To an extent, the doctrine of reasonable accommodation is influenced by this theory. However, scholars are recognising the symbiosis of rationality and emotions. ${ }^{125}$

\footnotetext{
120 Ibid. 311.

121 William Ian Miller, The Anatomy of Disgust (Harvard University Press 1998).

122 Bandes (ed), The Passions of Law (n 46).

123 The rubric of best possible correction is a vivid example of medicalisation of blindness, and it is not clear whether the certifying authority can insist an applicant go for the best possible correction before issuing the certificate. The law is also silent on who should incur the costs for such corrections. The rubric also opens up the possibility that if a person can become typical after the best possible correction, i.e., if she can regain her sight, then the decision of the certifying authority should be kept in abeyance till the execution of the best possible correction procedure. The import of the word 'best' is also highly susceptible to subjective interpretations. This rubric creates vast potential for the government bodies to throw in doubt the disability certificates issued by the competent authority. Even the courts may prefer a version of disability, relative to the so-called qualifications of a particular profession.

124 Bruce E Kaufman, 'Emotional Arousal as a Source of Bounded Rationality' (1999) 38(2) Journal of Economic Behavior and Organization.

125 See Eric A Posner, 'Law and the Emotions' (2000) U Chicago Law \& Economics, Olin Working Paper No. 103.
} 
The feminist legal theory also instantiates this approach by focusing on the historical linkage between law and emotion and reveals how both have been devalued. This approach has a vast potential to grow and capture other areas; particularly, the domain of disability laws.

As command of the sovereign, ${ }^{126}$ a system of rules, ${ }^{127}$ or as a hierarchy of norms ${ }^{128}$ in Kelsenian terms, positivist conception of law is consciously biased towards typical and able-bodied and is oblivious to the temporal progression of human life. On the other hand, the disability-inclusive legal theory accounts for the interaction of socio-economic and cultural barriers with physical and mental impairments and is cognisant of the lived experiences of PWDs. With the adoption of UNCRPD, a case is made for a polyphonic and multi-sited theory of law and its liberation from the hegemony of ableism. An inclusive conception of law is both instrumentally and intrinsically imperative for the transformation of justice and to contest the notion of a liberal and autonomous subject from the vintage of vulnerability. ${ }^{129}$ For the accomplishment of this objective, the institution of law should be predicated by the reference point of diverse humanity rather than able-bodism. In other words, the law must cater and recognise the difference and aim at equality of result rather than promoting equal opportunities on the plank of formal equality.

To establish the point, let me analyse Section 3 of the RPwD Act.

\subsubsection{Section 3 of RPWD Act: a critique}

Unlike Article 5(1) of UNCRPD, emphasising on doctrines of equality before the Law, equal protection of law, equality under the law and equal benefit of the law, ${ }^{130}$ the language of Section 3 of RPwD Act is intriguing because it does not explicitly vest the right to equality in PWDs.

Section 3(3) of this Act by outlawing disability-based discrimination and providing the license to State to discriminate for legitimate aims blows hot and cold and is patently unconstitutional. I argue against drawing any correlation with Section 15(1) (b) of the UK's Equality Act 2010, ${ }^{131}$ despite the former mirroring the latter. ${ }^{132}$ The

\footnotetext{
${ }^{126}$ John Austin, The Province of Jurisprudence Determined (Wilfrid Rumble (ed), Cambridge University Press 1995).

${ }^{127}$ H L A Hart and Leslie Green, Concept of Law (Joseph Raz and Penelope A Bulloch (eds.), Oxford University Press 2012).

128 Hans Kelsen, Pure Theory of Law (Translated by Max Knight, University of California Press 1967).

129 Jain, Towards Unrestricted and Disability Inclusive Legal Theory: Random Reflections' (n 14).

${ }^{130}$ UNCRPD art 5.

131 The Equality Act 2010, c 15 (UK) s 15(1)(b), 'A person (A) discriminates against a disabled person (B) if $-[\ldots]$ (b) A cannot show that the treatment is a proportionate means of achieving a legitimate aim.'

${ }^{132}$ See Lawson Anna, 'Disability and Employment in the Equality Act 2010: Opportunities Seized, Lost and Generated' (2011) 40(4) Industrial Law Journal 359, 362. Lawson argues that Section 15(1)(b) is not incompatible either with Article 5 or letter and spirit of UNCRPD. Relying on the earlier precedent she supports section 15(1)(b) as justification defence against indirect discrimination. However, I tend to agree with Butlin who finds the section to be incompatible with Article 5 of UNCRPD as the latter does not contain any such justification defence explicitly, S Fraser Butlin, 'The UN Convention on the
} 
latter extends to private actions and focuses on indirect discrimination, whereas the former implicates the State and addresses direct discrimination.

Secondly, the language of the UK's Equality Act 2010, is positive, and the onus is on the individual to prove that the treatment meted out to PWD by him is proportionate to counter the charge of discrimination; whereas Section 3(3) of RPwD Act provides licence to the State to discriminate both by acts or omissions and overlooks the aspect of the burden of proof. Conventionally, in India, the burden of proof is on the petitioner/claimant, and it is also an established practice to presume the constitutionality of both State action and inaction and treat it with deference and latitude. As a matter of fact, the degree of the latitude may be higher regarding actions that are perceived as involving expertise or special knowledge, i.e., decisions that are not run of the mill.

Thirdly, the proviso to Section 3(3) of RPwD Act undercuts the doctrine of reasonable classification by conferring almost unrestricted power on the state to discriminate on the ground of disability and can operate very regressively under the shadow of the doctrine of 'only on grounds of.' Discrimination is condonable per se, even on the ground of disability for serving the legitimate aim. The State is not under the onus to even demonstrate that the discrimination is based on disability in addition to some other ground unlike the doctrine of 'only on grounds of' appearing in Articles 15 and 16 of the Constitution of India.

Fourthly, in sharp contrast with the UK, India has a written Constitution, and if it is assumed that equal protection of laws to every person on the territory of India is a constitutionally ordained axiom and regarded as one of the foundational values underlying it, then the proviso is doomed to be unconstitutional. Moreover, if Article 14 of the Indian Constitution is treated as counter-factual to the proviso to Section 3(3) of the RPwD Act and weighed against Article 4(4) of UNCRPD, then India as a State party to UNCPRD is guilty of giving a regressive turn to its equality jurisprudence. ${ }^{133}$ Even if it is argued that by implanting the principle of proportionality, the proviso has made it almost impossible for the State to fall back on it, we have to ask ourselves whether any consistent jurisprudence in India for the interpretation of the aforementioned doctrine has been evolved. Equally, can it not be argued that in an ableist regime hostile to respect for difference, any aim can be perceived as legitimate? For example, the judges of the Supreme Court of India not very long ago perceived the ineligibility of blind persons as judges in the lower court to be a legitimate aim. ${ }^{134}$ In short, without proper construction being placed on the words 'legitimate' and 'proportionate,' PWDs are at constant threat of hostile exclusion and stereotyping.

\footnotetext{
Footnote 132 (continued)

Rights of Persons with Disabilities: Does the Equality Act 2010 Measure up to UK International Commitments?' (2011) 40 Industrial Law Journal 428, 435-436.

133 UNCRPD art 4, 'Nothing in the present Convention shall affect any provisions which are more conducive to the realisation of the rights of persons with disabilities and which may be contained in the law of a State Party or international law in force for that State.'

134 V Surendra Mohan v State of Tamil Nadu (n 55).
} 
Lastly, Section 3 of the RPWD Act is under-incorporative qua Article 5 of UNCRPD as it fails to recognise the doctrines of equality under the law and equal benefits of the law. In fact, UNCRPD Committee has suggested India to delete Section 3(3) of RPwD Act.

Turning to Section 3(4) of RPwD Act, the narrative becomes even more crude. Unlike Article 21 of the Constitution of India which makes deprivation of life and personal liberty contingent on the procedure established by law, Section 3(4) of RPwD Act provides that 'No person shall be deprived of his or her personal liberty only on the ground of disability.' Interpreted plainly, Section 3(4) means a PWD may be deprived of his personal liberty on disability and some other ground simplicitor. Whether this clause does away with the requirement of deprivation procedure being just, fair, and reasonable is a moot question. Moreover, an extension of the ghost of 'only on the ground of' from Articles 15 and 16 of the Constitution to Section 3(4) of RPwD Act is the worst form of regression when considered against the backdrop of Article 359 of the Constitution of India as stood amended by the 44th Amendment ${ }^{135}$ to the Constitution making Article 21 non-derogable even during an emergency. Section 3(4) of RPwD Act has seriously watered down the nonderogability of Article 21 by considerably lowering the threshold of deprivation of the right to personal liberty by the State. Unlike the proviso to Section 3(3) of RPwD Act, which at least makes discrimination contingent on a legitimate aim, Section 3(4) of RPwD Act, in sharp contrast, requires only disability plus ground for the deprivation of personal liberty of PWDs.

The extension of the ghost of 'only on the ground of' to the deprivation of personal liberty is unprecedented. It sounds ominous, particularly because the right to personal liberty is one of the most sought-after rights by the appellate courts to create a host of unenumerated rights. Whereas, with Section 3(4) RPwD Act as a part of the statute book, the legislature has turned the scope of personal liberty upside down with no scope for expansion. This extraordinary combination of rights-violating clauses demonstrates beyond all doubts the public contempt, prejudice, and disdain for PWDs. These clauses are the embodiment of negative and ableist emotions haunting the destiny of PWDs.

Besides, the combination also perpetuates the stereotype that deprivation of personal liberty of PWDs on the disability-plus ground is justified. This assumption is a very clear manifestation of the able-bodied norm that if a PWD is perceived as danger to society, then his/her personal liberty may be dispensed with. Moreover, its scope is not confined to any specific disability. However, from the same, I should not be taken to mean that I advocate confined deprivation of personal liberty vis-avis any particular disability. Additionally, the power to deprive PWDs of their personal liberty is vested with the State unconditionally and without any guidance for its exercise.

135 The Constitution (Forty-fourth Amendment) Act 1978. 
It is necessary to resort to the technique of affirmative sabotage ${ }^{136}$ advocated by Gayatri Chakravorty Spivak in one of her stellar pieces ${ }^{137}$ to revitalise and effectively ignite all the aforementioned clauses of Section 3 by exposing how ableism creeps in to stereotype the stigmatising image of PWDs.

Overall, when we read Section 5 of RPwD Act, both its form and substance appear to have been stripped off the public emotions of compassion, empathy, and human dignity. In this connection, the views of a noted scholar, perceiving law from the vantage point of sentiments, are worth alluding to. Contesting the unsentimental conception of legal liberalism, she makes a case for what may be called inclusive legal liberalism. She observes, 'Integrity and moral connectivity is inconsistent, then, not only with pernicious or intrusive or discriminatory law,but also, with law's absence-by which I mean both the lack of law altogether, or the presence of a law that fails to protect or protect equally. ${ }^{138}$ According to Robin West, the protective core of law being germane to liberal legalism generates the public emotions of empathy, compassion, and dignity, and the legal order is infused by the same. Although, the law is clearly not a sufficient condition for the generation of moral sentiments yet, along with the protective core and recognition of the sense of ownership of one's own body, law generates necessary conditions for the creation and infusion of moral sentiment. ${ }^{139}$ On an epistemological plane, I agree with this view entirely because Robin West focuses not only on the presence of law but also critiques the absence of law from the perspective of protection. Thus, Section 3 of RPWD Act is more an instance of absence of law rather than fostering the protective core. ${ }^{140}$

\subsection{Legal actor approach}

This approach focuses on how legal actors like judges, juries, lawyers, and others are informed by and sensitive to emotions while accomplishing their tasks and performing their assigned roles. This prong has attracted the attention of a lot of scholars interested in empirical analysis. However, the analysis is mostly confined to the study of the attitudes of the jurors. Such an under-representative mapping does not provide any useful insight in relation to law-and-emotion scholarship in India as we have abolished the juror system. ${ }^{141}$ However, it is necessary to gauge the attitudes

\footnotetext{
136 By this technique, all the clauses have to be reinterpreted to contest and sabotage the ableist normativity of law. The technique can be deployed to demonstrate and expose the fake justifications for violations of human rights of PWDs.

137 See Gayatri Chakravorty, Can the Subaltern Speak? Reflections on The History of an Idea (Rosalind C Morris 2010).

138 West, 'Law's Sentiments' (n 18) 50.

139 Ibid.

140 Ibid.

141 K M Nanavati v State of Bombay (1961) 1 SCR 497. Also see James Jaffe, "“Not The Right People": Why Jury Trials were Abolished in India' (SLR-Socio-Legal Review, The National Law School of India University Bangalore, 1 October 2020). https://www.sociolegalreview.com/post/not-the-right-peoplewhy-jury-trials-were-abolished-in-india. Accessed 19 October 2021.
} 
of parliamentarians, bureaucrats, policymakers and judges to carefully analyse both the negative and positive role of emotions in their minds. ${ }^{142}$ Scholars like Saptarshi Mandal and Amita Dhanda have made attempts to expose the negative role of emotions, particularly disgust in judicial and legislative processes in the context of the testimony of disabled witnesses and persons with unsound minds. ${ }^{143}$ Similarly, Upendra Baxi has tried to view the marginalisation of PWDs from the vantage point of causation of disability rather than its carriers. ${ }^{144}$ The notion of Constitutional renaissance evolved by Baxi ${ }^{145}$ while engaging with Dipak Mishra, ex-Chief Justice of India, is most illuminating. ${ }^{146}$

To reiterate, the above six-prong approaches render assistance in mapping the nuanced compass of law and emotion debate rather than as fixed focal points.

\section{Conclusion}

As has been very rightly pointed out by Nussbaum and Maroney, the majority of the scholars focus their attention on negative emotions like shame, disgust, fear, and anger, whereas, very little or no attention has been paid to the interaction of positive emotions like empathy, dignity and compassion with law. There is a vast potential to generate empirical data to examine and analyse the impact of ableist legal hegemony on PWDs, how Constitutions of certain jurisdictions foster ideas of empathy and inclusion, and condemn their alienation, exclusion, and dehumanisation. UNCRPD being the Magna Carta of the rights of PWDs acknowledges the public emotion of inherent human dignity, the same has to be percolated in the legal consciousness of Constitutions around the world.

Similarly, we should not lose sight of emotional phenomenon like fraternity, equanimity and affection, and care in building and sustaining societies, and lay emphasis on theorising the same. ${ }^{147}$

This paper has grappled with a vital question — should emotions play any role in the enacting, interpreting, and understanding the law? In my opinion, the answer to the above question is an emphatic yes. To allude to Nussbaum, the institution of law is indeed a double-edged sword by simultaneously being an instrument of

\footnotetext{
142 See L Rheault, K Beelen, G Cochrane, G Hirst, 'Measuring Emotion in Parliamentary Debates with Automated Textual Analysis' (2016) 11(12) Plos One.

143 Saptarshi Mandal, 'The Burden of Intelligibility: Disabled Women's Testimony in Rape Trials' (2013) 20(1) Indian Journal of Gender Studies 1; Saptarshi Mandal, 'Adjudicating Disability: Some Emerging Questions' (2010) 45(49); Amita Dhanda, Legal Order and Mental Disorder (SAGE Publications Pvt Ltd 1999).

144 Upendra Baxi, 'The Deeper Meaning of Disability: Ambedkar and Social Theory of Disability' forthcoming in Dr Sanjay Jain and Tressa Paul (eds.), Combating Exclusion, Embracing Inclusion: Critical and Analytical Essays on Disability Rights Jurisprudence and the Empowerment of PWDs.

145 Baxi, 'A Constitutional Renaissance' (n 106).

146 Manoj Narula v Union of India (2014) 9 SCC 1.

147 In my opinion, the emphasis of Jones on behavioural biology and evolutionary history of human emotions is deeply ableist. See Owen D Jones, 'Law, Emotions, and Behavioral Biology' (1999) 39(3) Jurimetrics 289.
} 
exclusion along with a powerful socio-political institution to remove the stigma. ${ }^{148}$ Since the other of the law or outside the law is symptomatic of anarchy and disorder, it is preeminent to keep the faith in law going. By being under the fold of law or its protective core the legal agents seek to strengthen their sense of ownership on their bodies and foster respect and empathy for others. Only with the presence of legal rules, and not in their absence, adequacies or inadequacies of the same may be debated. As outliers, it would be difficult, if not impossible, for PWDs to dispute or question the degree of recognition. Therefore, I endorse Robin West in her assertion that 'the protection of law is a condition of moral sentiments. When the law protects us, there is more room not only for equality but also for a fully moral human life, enriched by passion, attachment, intimacy, and community. ${ }^{149}$ For the same, we have to generate a very meaningful interplay of law and emotions, which would be sensitive to the 'sayings and doings' in the Ambedkarian sense and be cognizant of the productivity of the PWDs.

Acknowledgements I wish to dedicate this article to Late Prof. Dr. Shirish Deshpande's fond memories.

\section{Declarations}

Conflict of interest The author has no conflict of interest to declare that are relevant to the content of this article.

Publisher's Note Springer Nature remains neutral with regard to jurisdictional claims in published maps and institutional affiliations.

148 Nussbaum, Hiding from Humanity (n 1) 310.

149 West, 'Law's Sentiments' (n 18) 59. 